\title{
Muskrat Ecology in the Mackenzie Delta: Insights from Local Knowledge and Ecological Field Surveys
}

\author{
by Chanda Brietzke
}

\section{INTRODUCTION}

$\mathrm{A}^{\mathrm{n}}$ RCTIC DELTAS HAVE BEEN CALLED KEYSTONE ECOSYSTEMS because of the numerous processes they influence at the land-ocean interface, such as nutrient cycling and sea ice formation (Lesack et al., 2014). Climate change is proceeding more rapidly in the Arctic than in any other region (ACIA, 2004), and low-lying Arctic deltas are expected to be significantly affected by the combined effects of changes in both terrestrial and marine environments (Walker, 1998). Terrestrial changes that are particularly concerning include increases in summer precipitation and the altered timing of spring breakup (Goulding et al., 2009; Lesack et al., 2014). Marine processes, including sea level rise, increased storm surge activity, and reduced sea ice cover will also affect Arctic deltas (ACIA, 2004; Lantz et al., 2015).

The Mackenzie Delta in Canada's western Arctic, the second largest Arctic delta in the world, is a low-lying alluvial plain that contains thousands of small lakes (Emmerton et al., 2007) (Fig. 1). The numerous water bodies in the delta offer abundant habitat for fish, birds, and mammals, including muskrats (Ondatra zibethicus). Muskrats are semiaquatic furbearers whose populations respond to water levels and may serve as an indicator species for changes in wetland ecosystems (Fuller, 1951; Weller, 1988). They are prey species for marten, mink, red fox, black bear, otter, wolves, and grizzly bears (Fuller, 1951; Jelinski, 1989) and can have significant effects on the vegetation in their habitat (Errington, 1963; Nyman et al., 1993; Smirnov and Tretyakov, 1998).

Muskrats also supported a prolific fur and subsistence economy in the North throughout the 19th and 20th centuries (Stevens, 1953; Krech, 1976; Alunik et al., 2003). While participation in the fur trade has declined since the 1950s as a result of low fur prices and the high cost of trapping, muskrats remain important culturally and economically and are still used for subsistence and income (Gwich'in Elders, 1997; A. Gordon, pers. comm. 2013).

Like other northern mammals, muskrats exhibit periodic cycles in population size (Errington, 1963; Krebs, 1996). It has been suggested that these cycles are caused by disease outbreaks, predator population cycles, and intrinsic and external factors (Erb et al., 2000; Krebs, 2013). Research on fur returns from the Mackenzie Delta in the late $1800 \mathrm{~s}$ to early 1900 s indicates that population cycles in the delta average around 10 years between highs (Clarke, 1944). In recent years, many residents of the Mackenzie Delta region have reported declines in muskrat abundance that are outside the normal range of variation (ABEKS, 2003, 2008).

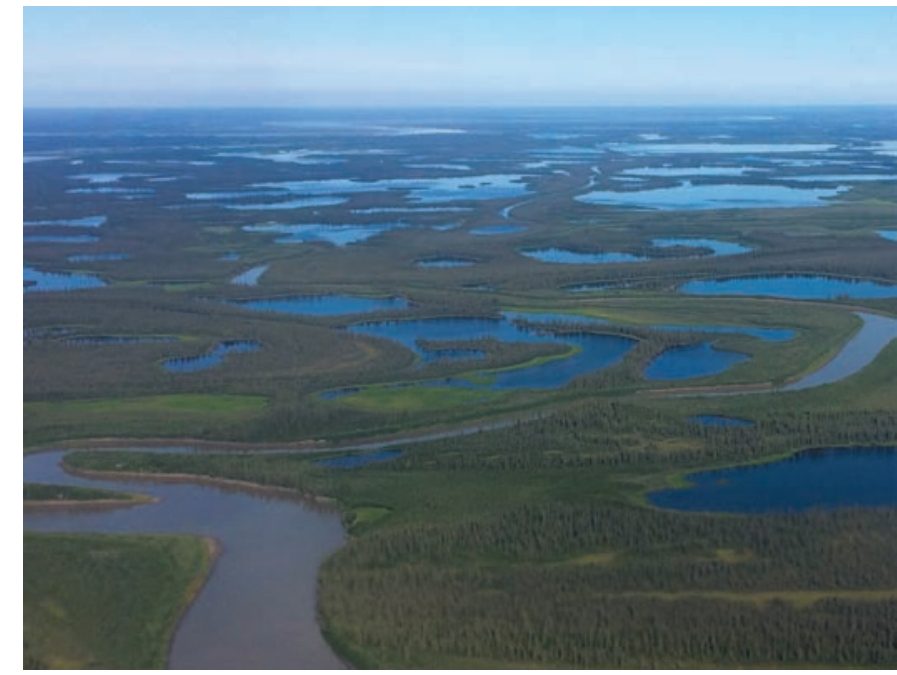

FIG. 1. Aerial photograph of lakes near East Channel, upstream of Inuvik in the Mackenzie Delta, Northwest Territories. Photo by Chanda Brietzke.

This decline is likely to have significant impacts on local communities that rely on muskrats for subsistence, trapping income, and overall wellbeing (Parlee et al., 2005; Gill et al., 2014) and may be related to changes in the climate and hydrological processes in the Mackenzie Delta.

The primary objective of my research is to investigate reported declines in muskrat populations and examine linkages between habitat use and biophysical conditions in the Mackenzie Delta. The traditional knowledge held by land users, informed by the experiences of past and present generations, is a valuable resource for understanding why, when, and where changes in muskrat ecology and harvesting have taken place. In the first part of my research, I explore the insights that local knowledge holders provide regarding changes in muskrat ecology and harvesting practices in the Mackenzie Delta over the last 100 years. In the second part of my research, I use field surveys to identify and characterize biophysical conditions linked to muskrat habitat use.

\section{MUSKRAT ECOLOGY}

Muskrats live in still and slow-moving water bodies throughout North America and are found in lakes in the Mackenzie Delta. In the summer, they consume emergent shoreline vegetation (Equisetum fluviatile) and some submerged macrophytes (Potamogeton spp.), but in the winter their diet is restricted to the roots and rhizomes of 


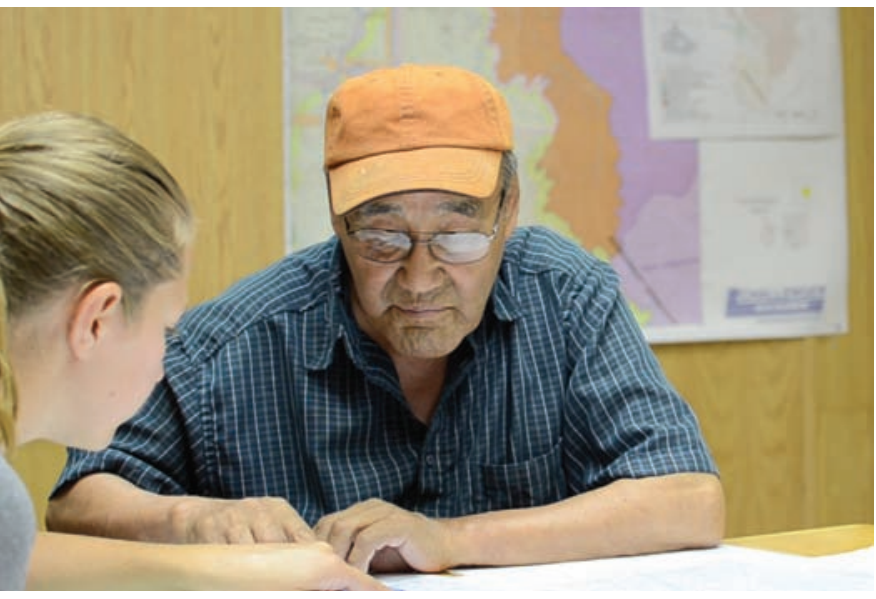

FIG. 2. Neil Snowshoe (Fort McPherson) points out the locations of his observations on a map in an interview with Chanda Brietzke. Photo by Paige Bennett.

submerged macrophytes that persist on lake bottoms under the ice (Jelinski, 1989). To extend their feeding range and survive the northern winter, muskrats move their burrow locations adjacent to deeper water (Jelinski, 1989) and construct push-ups - mounds of vegetation insulating an ice hole and a feeding platform (Stevens, 1955). Muskrats move burrow locations because they require an abundance of submerged macrophytes for food and the presence of water that does not freeze to the bottom during the winter (Stevens, 1955). The availability of sufficient winter habitat is likely a fundamentally limiting factor for northern muskrat populations (Stevens, 1955), and adequate lake depth and macrophyte productivity may be important determinants of muskrat winter lake occupancy.

Submerged macrophyte productivity and community composition vary significantly among lakes in the Mackenzie Delta (Squires and Lesack, 2003) and likely affect winter habitat quality. Factors influencing macrophyte productivity and community composition in delta lakes are strongly related to the frequency and duration of spring flooding by the Mackenzie River (Squires and Lesack, 2003). Lakes in the delta can be divided into three categories based on their flooding regimes: no closure (lakes are connected to the river all summer); low closure (lakes flood in the spring, annually); and high closure (lakes flood in the spring, but not every year) (Marsh and Hey, 1989). Documented biophysical differences between these closure classes include lake transparency and sedimentation rates (Marsh et al., 1999; Squires et al., 2002); amount of lake water renewal from the river (Lesack and Marsh, 2010); stability of water solute chemistry, including $\mathrm{pH}$ and nutrient levels (Lesack et al., 1998); nutrient and organic matter content of sediment (Squires and Lesack, 2003); and macrophyte community composition and productivity (Squires et al., 2002; Squires and Lesack, 2003).

Closure class may also affect habitat suitability directly: local knowledge suggests that no-closure lakes are not good winter muskrat habitat because push-ups can be

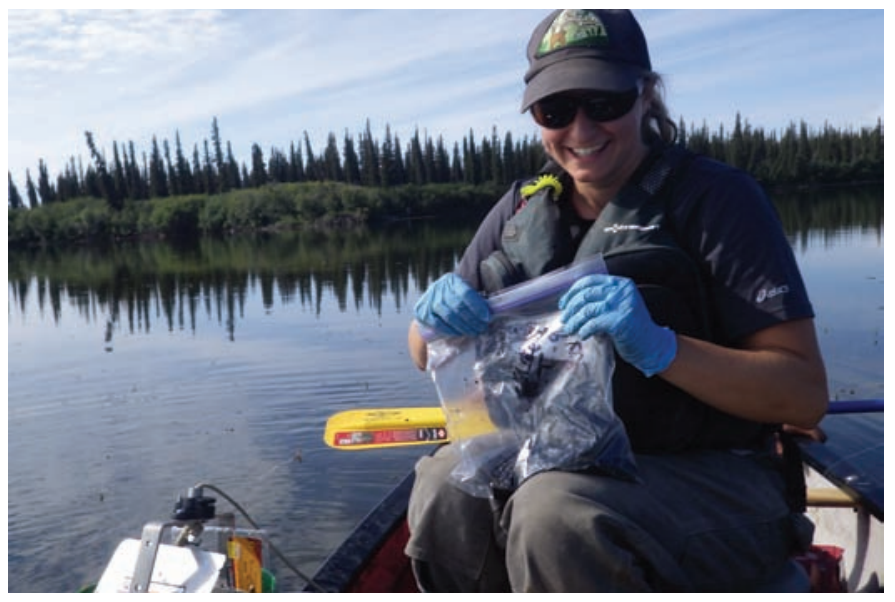

FIG. 3. Chanda collecting a sediment sample on a lake in the Mackenzie Delta. Photo by Paige Bennett.

destroyed when water levels decrease in the fall and the ice drops down (J. Rogers, pers. comm. 2014). In the PeaceAthabasca Delta, declines in muskrat populations have corresponded with reductions in spring flooding over the last 40-50 years (PADEMP, 2014), leading park managers to conclude that spring flooding may be critical to sustaining muskrat populations. Trappers in the Mackenzie Delta also suggest that some degree of flooding, whether yearly or less often, is necessary for productive trapping lakes (D. Esagok, pers. comm. 2014). Flooding frequencies in the delta are likely to change with altered climatic conditions, including earlier and warmer spring breakups and changes in the timing of spring melt (Goulding et al., 2009; Lesack et al., 2014), which will in turn affect the biophysical parameters noted above.

\section{METHODS}

To ensure the relevance of my research to community members, I have and will continue to pursue a collaborative research methodology. Research objectives and methods for this project were developed jointly with numerous community organizations in the Mackenzie Delta, including the Gwich'in Renewable Resource Councils (RRCs) in Inuvik, Aklavik, Fort McPherson, and Tsiigehtchic, the Gwich'in Renewable Resources Board (GRRB), and the Gwich'in Social and Cultural Institute (GSCI). I will continue to work with these organizations and delta residents during the data collection, analysis, and writing stages. Support and collaboration from these organizations is required to conduct research that is meaningful to the communities in the Mackenzie Delta.

In the summers of 2014 and 2015, I conducted 10 semistructured map-based interviews with 13 participants. Potential participants were contacted by an interview coordinator from Fort McPherson, Northwest Territories, who arranged and took part in the interviews. Gwich'in and Inuvialuit traditional knowledge holders were asked a series of 
predetermined questions that focused on their knowledge and experiences of muskrat health, habitat, harvesting, and population dynamics. Maps of the area were provided during the interviews to allow respondents to indicate specific places where observations were made (Fig. 2). In March of 2016, I will conduct additional interviews on the land and visit at least one muskrat trapping camp and trapline.

All interviews will be transcribed and coded using themes that reflect the nature and location of the observations. To explore the collective knowledge of muskrat ecology in the region, I will examine points of similarity and divergence among participants and assess spatial patterns in the observations.

To document muskrat lake use of the delta in winter, an aerial photo survey of 3300 lakes was conducted in collaboration with the GRRB and McGill University. This photographic survey was completed from 21 to 22 May 2015, prior to the breakup of the Mackenzie River, when muskrat push-ups were visible on the ice-covered lake surfaces. Survey photos will be used to examine individual lakes for evidence of muskrat push-ups. The closure class of each lake surveyed was determined using data from Marsh et al. (1999).

To characterize biophysical conditions among closure classes in the summer of 2015, I conducted field surveys at a total of 44 lakes (Fig. 3). In each lake, I took measurements of $\mathrm{pH}$, conductivity, temperature, turbidity, and lake depth. At the mid-point of each transect, I collected a water sample, which was analyzed for nutrient content (total N and $\mathrm{P}$ ), and a sediment sample, which will be analyzed for sediment chemistry (total nitrogen, total carbon, total phosphorus, and elements including $\mathrm{Ca}, \mathrm{Mg}$, and $\mathrm{K}$ ) and organic matter content. At three points along each transect, I collected submerged macrophyte standing crop samples from the lake bottom. These samples were identified and sorted by species, dried in ovens at $100^{\circ} \mathrm{C}$, and weighed to provide a measure of overall biomass and community composition (Squires and Lesack, 2003; Johnson and Newman, 2011).

\section{PRELIMINARY RESULTS}

Interview participants discussed many aspects of muskrat ecology and harvesting in the Mackenzie Delta. Emergent themes include 1) economic and social changes in the last 50 years and their effects on muskrat harvesting; 2) changing beaver, otter, and muskrat interactions; and 3) muskrat population dynamics. Many interview participants asserted that water levels and spring flooding strongly influence muskrat populations, but responses also indicated that changes in muskrat populations have not occurred consistently in all areas of the delta. However, numerous interviewees stressed that recent declines in muskrat numbers have been more extensive and ongoing than declines witnessed in the past. Further analysis of interview responses will explore spatial patterns and population dynamics discussed by participants. Ongoing analysis of ecological data will also contribute to our understanding of the biophysical drivers of muskrat lake use in the winter months and their potential impact on population dynamics.

\section{ANTICIPATED SIGNIFICANCE}

This project emerged out of community concerns that muskrats are declining in the Mackenzie Delta, and many delta residents are very interested in the findings. To ensure that my analysis is accessible to residents, I will produce a booklet detailing the results of my research for use in schools or other educational programs and will present my findings at community meetings in the spring of 2016. I hope that by involving youth and community members in field surveys and interviews, this project will also increase the regional capacity for community-based ecological monitoring and traditional knowledge studies.

This research will also contribute to our understanding of muskrat habitat use and selection, which will inform decisions made by local co-management bodies responsible for wildlife in the delta, including the Gwich'in Renewable Resources Board and the Inuvialuit Game Council. As climate change continues to affect the hydrology and ecosystem functioning of the delta, insights into how muskrat populations may respond will be valuable to these organizations.

There are a number of long-term muskrat monitoring initiatives in the North that will contribute to a broader picture of regional patterns and trends. Ongoing surveys of muskrat push-up abundance are being conducted in the Old Crow Flats, Yukon Territory, and the Peace-Athabasca Delta in Wood Buffalo National Park, Alberta, as part of studies examining the health and functioning of these ecosystems (PADEMP, 2014; Straka et al., 2014; J. Brammer, pers. comm. 2015). Aerial surveys of muskrat push-ups in the Mackenzie Delta will be repeated for at least two more years, providing a longitudinal data set that will contribute to a better understanding of population dynamics. Collectively, muskrat research in the Yukon, Northwest Territories, and Alberta will contribute to our understanding of how ongoing climate change in northern regions will affect this species and the people who rely on it.

\section{ACKNOWLEDGEMENTS}

I am immensely honoured to have been awarded the 2015 Lorraine Allison Memorial Scholarship, and I thank the selection committee and the Arctic Institute of North America. I am very grateful to my supervisor, Dr. Trevor Lantz, and professors Dr. Natalie Ban and Dr. Brian Starzomski for their support. I also thank the Gwich'in Renewable Resources Board, the Gwich'in Social and Cultural Institute, the Gwich'in Renewable Resource Councils of Fort McPherson, Tsiigehtchic, Inuvik, and Aklavik, and the Inuvik Hunters' and Trappers' Committee for their support and contributions to my research. This research would 
not have been possible without the assistance and commitment of numerous individuals from these organizations and the Lantz lab. I would also like to thank my research assistants, Paige Bennett and Kazlyn Bonnor, for making the 2015 field season possible, and Doug Esagok, for guidance on delta navigation and all things muskrat. Youth participants from the Gwich'in Youth Work Experience Program and Laura Nerysoo of Fort McPherson were instrumental in ecological fieldwork and interview coordination, respectively. Additional funding for this research was provided by a Social Sciences and Humanities Research Council Canada Graduate Scholarship, the Natural Sciences and Engineering Research Council of Canada, the Northern Scientific Training Program, the Aurora Research Institute Research Assistant Program, the Gwich'in Renewable Resources Board Wildlife Studies Fund, the Aboriginal Fund for Species at Risk from Environment Canada, a University of Victoria Graduate Fellowship, a University of Victoria President's Research Scholarship, and a W. Garfield Weston Award for Northern Research.

\section{REFERENCES}

ABEKS (Arctic Borderlands Ecological Knowledge Society). 2003. Proceedings of the Arctic Borderlands Ecological Knowledge Co-op: 7th Annual Gathering, 28 February-2 March 2002, Fort McPherson, Northwest Territories. Report 2002-1. Whitehorse, Yukon: Arctic Borderlands Ecological Knowledge Society.

- 2008. Proceedings of the Arctic Borderlands Ecological Knowledge Co-op: 11th Annual Gathering, 29-30 March 2008, Inuvik, Northwest Territories. Whitehorse, Yukon: Arctic Borderlands Ecological Knowledge Society.

ACIA (Arctic Climate Impact Assessment) 2004. Impacts of a warming Arctic. Cambridge: Cambridge University Press.

Alunik, I., Kolausok, E.D., and Morrison, D. 2003. Across time and tundra: The Inuvialuit of the Western Arctic. Vancouver, British Columbia: Raincoast Books.

Clarke, C.H.D. 1944. Notes on the status and distribution of certain mammals and birds in the Mackenzie River and western Arctic area in 1942 and 1943. Canadian Field-Naturalist 58(3):97-103.

Emmerton, C.A., Lesack, L.F.W., and Marsh, P. 2007. Lake abundance, potential water storage, and habitat distribution in the Mackenzie River Delta, western Canadian Arctic. Water Resources Research 43(5), W05419. http://doi.org/10.1029/2006WR005139

Erb, J., Stenseth, N.C., and Boyce, M.S. 2000. Geographic variation in population cycles of Canadian muskrats (Ondatra zibethicus). Canadian Journal of Zoology 78(6):1009-1016. http://dx.doi.org/10.1139/z00-027

Errington, P.L. 1963. Muskrat populations. Ames: Iowa State University Press.

Fuller, W.A. 1951. Natural history and economic importance of the muskrat in the Athabasca-Peace Delta, Wood Buffalo Park. Wildlife Management Bulletin, Series 1, No. 2. Ottawa, Ontario: Canadian Wildlife Service.
Gill, H., Lantz, T., and the Gwich'in Social and Cultural Institute. 2014. A community-based approach to mapping Gwich'in observations of environmental changes in the Lower Peel River Watershed, NT. Journal of Ethnobiology 34(3):294-314. http://dx.doi.org/10.2993/0278-0771-34.3.294

Goulding, H.L., Prowse, T.D., and Bonsal, B. 2009. Hydroclimatic controls on the occurrence of break-up and ice-jam flooding in the Mackenzie Delta, NWT, Canada. Journal of Hydrology 379(3-4):251-267.

http://dx.doi.org/10.1016/j.jhydrol.2009.10.006

Gwich'in Elders. 1997. Nành' Kak Geenjit Gwich'in Ginjik / Gwich'in words about the land. Inuvik, Northwest Territories: Gwich'in Renewable Resource Board.

Jelinski, D.E. 1989. Seasonal differences in habitat use and fat reserves in an Arctic muskrat population. Canadian Journal of Zoology 67(2):305-313.

http://dx.doi.org/10.1139/z89-045

Johnson, J.A., and Newman, R.M. 2011. A comparison of two methods for sampling biomass of aquatic plants. Journal of Aquatic Plant Management 49:1-8.

Krebs, C.J. 1996. Population cycles revisited. Journal of Mammalogy 77(1):8-24.

http://dx.doi.org/10.2307/1382705

- 2013. Population fluctuations in rodents. Chicago: University of Chicago Press.

Krech, S., III. 1976. The Eastern Kutchin and the fur trade, 1800 - 1860. Ethnohistory 23(3):213-235.

http://dx.doi.org/10.2307/481253

Lantz, T.C., Kokelj, S.V., and Fraser, R.H. 2015. Ecological recovery in an Arctic delta following widespread saline incursion. Ecological Applications 25(1):172 - 185.

http://dx.doi.org/10.1890/14-0239.1

Lesack, L.F.W., and Marsh, P. 2010. River-to-lake connectivities, water renewal, and aquatic habitat diversity in the Mackenzie River Delta. Water Resources Research 46(12), W12504. http://dx.doi.org/10.1029/2010WR009607

Lesack, L.F.W., Marsh, P., and Hecky, R.E. 1998. Spatial and temporal dynamics of major solute chemistry among Mackenzie Delta lakes. Limnology and Oceanography 43(7):1530 - 1543. http://dx.doi.org/10.4319/1o.1998.43.7.1530

Lesack, L.F.W., Marsh, P., Hicks, F.E., and Forbes, D.L. 2014. Local spring warming drives earlier river-ice breakup in a large Arctic delta. Geophysical Research Letters 41(5):1560-1567. http://dx.doi.org/10.1002/2013GL058761

Marsh, P., and Hey, M. 1989. The flooding hydrology of Mackenzie Delta lakes near Inuvik, NWT, Canada. Arctic 42(1):41-49. http://dx.doi.org/10.14430/arctic1638

Marsh, P., Lesack, L.F.W., and Roberts, A. 1999. Lake sedimentation in the Mackenzie Delta, NWT. Hydrological Processes 13(16):2519-2536.

http://dx.doi.org/10.1002/(SICI)1099-1085(199911)13:16<2519:: AID-HYP935>3.0.CO;2-T

Nyman, J.A., Chabreck, R.H., and Kinler, N.W. 1993. Some effects of herbivory and 30 years of weir management on emergent vegetation in Brackish Marsh. Wetlands 13(3):165 - 175. http://doi.org/10.1007/BF03160877 
PADEMP (Peace-Athabasca Delta Ecological Monitoring Program). 2014. The Flow: News from the Peace-Athabasca Delta Ecological Monitoring Program. Volume 1, Issue 1 (December). Wood Buffalo National Park: PADEMP.

http://pademp.com/wp-content/uploads/2014/12/PADEMPnewsletter-issue-one-final.pdf

Parlee, B., Berkes, F., and Teetl'it Gwich'in. 2005. Health of the land, health of the people: A case study on Gwich'in berry harvesting in northern Canada. EcoHealth 2(2):127-137. http://doi.org/10.1007/s10393-005-3870-z

Smirnov, V.V., and Tretyakov, K. 1998. Changes in aquatic plant communities on the island of Valaam due to invasion by the muskrat Ondatra zibethicus L. (Rodentia, Mammalia). Biodiversity and Conservation 7(5):673-690. http://dx.doi.org/10.1023/A:1008860603166

Squires, M.M., and Lesack, L.F.W. 2003. The relation between sediment nutrient content and macrophyte biomass and community structure along a water transparency gradient among lakes of the Mackenzie Delta. Canadian Journal of Fisheries and Aquatic Sciences 60(3):333-343. http://dx.doi.org/10.1139/f03-027

Squires, M.M., Lesack, L.F.W., and Huebert, D. 2002. The influence of water transparency on the distribution and abundance of macrophytes among lakes of the Mackenzie Delta, Western Canadian Arctic. Freshwater Biology 47(11):2123-2135. http://dx.doi.org/10.1046/j.1365-2427.2002.00959.x
Stevens, W.E. 1953. The northwestern muskrat of the Mackenzie delta, Northwest Territories, 1947-48. Wildlife Management Bulletin, Series 1, No. 8. Ottawa, Ontario: Canadian Wildlife Service.

- 1955. Adjustments of the Northwestern muskrat (Ondatra zibethicus spatulatus) to a northern environment. PhD dissertation, University of British Columbia, Vancouver.

Straka, J., Gray, Q., and MacMillan, S. 2014. Maintaining connections: Learning through monitoring in the PeaceAthabasca Delta: Summary report of the 2nd forum hosted by the Peace-Athabasca Delta Ecological Monitoring Program (PADEMP) in Fort Chipewyan, Alberta, February 18th -19 th, 2014. Wood Buffalo National Park: PADEMP. http://pademp.com/wp-content/uploads/2015/01/PADEMPForum2_FinalReport.pdf

Walker, H.J. 1998. Arctic deltas. Journal of Coastal Research 14(3):719-738.

Weller, M.W. 1988. Issues and approaches in assessing cumulative impacts on waterbird habitat in wetlands. Environmental Management 12(5):695-701. http://dx.doi.org/10.1007/BF01867546

Chanda Brietzke is the 2015 recipient of the Lorraine Allison Scholarship. She is currently a Master of Science student in the School of Environmental Studies, University of Victoria. E-mail: ckbrietzke@gmail.com 